\title{
BAHASA INDONESIA SEBAGAI MEDIA KOMUNIKASI
}

\author{
RANITA SARI
}

175100004

Universitas Mitra Indonesia, Sistem Informasi

ranitasari.student@umitra.ac.id

\begin{abstract}
Abstrak
Bahasa Indonesia kini telah menjadi bahasa potensial untuk dipelajari oleh masyarakat Internasional dikarenakan kemajuan yang ditunjukkan Indonesia di segala sektor, utamanya bidang ekonomi. Salah satu fungsi dari bahasa adalah sebagai alat komunikasi. Untuk memahami satu sama lain dalam proses komunikasi diperlukan pemahaman yang sama dalam bahasa yang digunakan. Selain itu bahasa juga dipandang sebagai lambang identitas sebuah komunitas atau negara. Oleh karena itu, keberadaan sebuah bahasa menjadi hal yang sangat penting. Media komunikasi sangat berperan penting bagi kehidupan masyarakat. Secara sederhana, sebuah media komunikasi adalah sebuah perantara dalam menyampaikan sebuah informasi dari komunikator kepada komunikan yang bertujuan agar efisien dalam menyebarkan informasi atau pesan. Komunikasi merupakan bentuk percakapan yang berlangsung atas dasar persamaan persepsi. Sebagai alat komunikasi, bahasa merupakan saluran perumusan maksud kita, melahirkan perasaan kita dan memungkinkan kita menciptakan kerja sama dengan sesama warga. Ia mengatur berbagai macam aktivitas kemasyarakatan, merencanakan dan mengarahkan masa depan kita (Gorys Keraf, 1997 : 4).

Kata Kunci : Bahasa, Media, Komunikasi.
\end{abstract}

\section{A.CAPTURE}

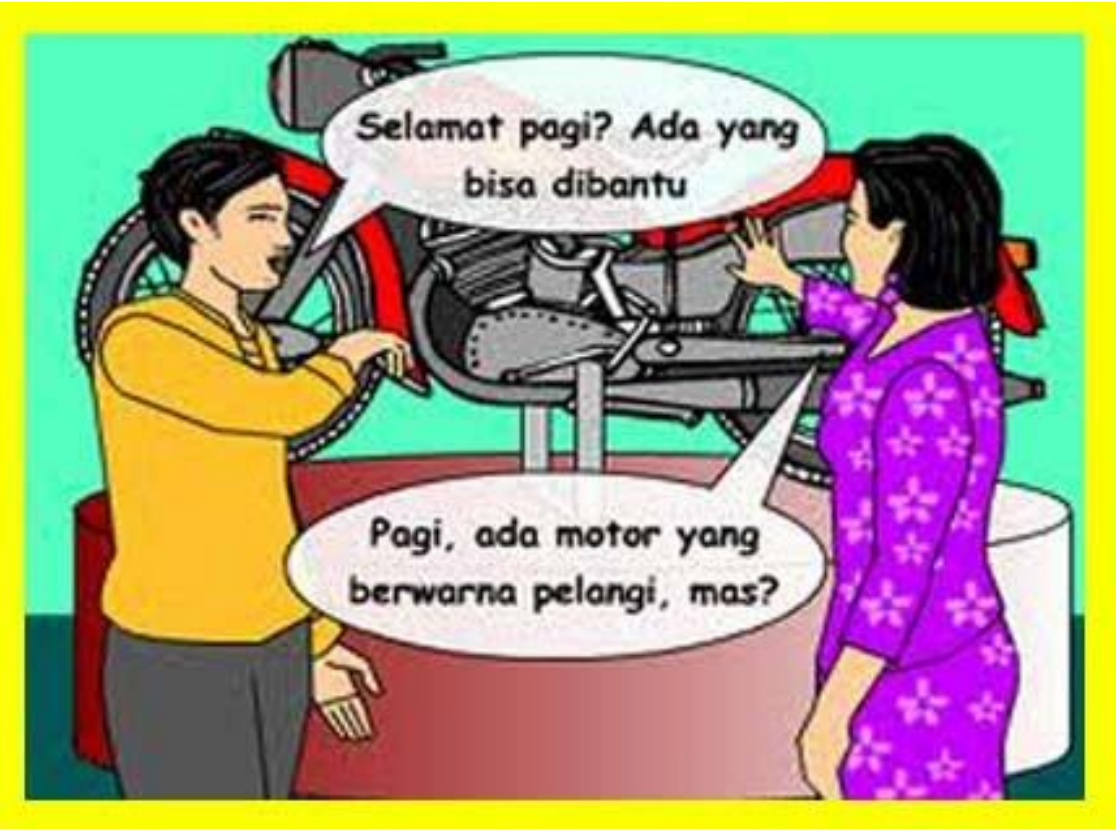




\section{B.PENJELASAN}

Menurut Gorys Keraf (2004 : 1), bahasa adalah alat komunikasi antara anggota masyarakat berupa simbol bunyi yang dihasilkan oleh alat ucap manusia. Ketika anggota masyarakat menginginkan untuk berkomunikasi dengan sesamanya, maka orang tersebut akan menggunakan suatu bahasa yang sudah biasa digunakannya untuk menyampaikan sesuatu informasi. Pada umumnya bahasa-bahasa tersebut dapat berbeda antara satu daerah dengan daerah yang lain, hal ini dapat dikarenakan adanya perbedaan kultur, lingkungan dan kebiasaan yang mereka miliki. Mungkin asumsi beberapa orang berpendapat bahwa tidak hanya bahasa saja yang dapat dijadikan sebagai media komunikasi. Mereka menunjukkan bahwa terdapat dua orang atau lebih yang mengadakan komunikasi dengan mempergunakan cara-cara tertentu yang telah disepakati bersama. Mereka memakai beberapa alat ataupun media untuk menyampaikan suatu kabar yang memang ingin diinformasikan kepada pihak lain dengan menggunakan lukisanlukisan, asap api, bunyi gendang atau tong-tong dan sebagainya.

Menurut KBBI (Kamus Besar Bahasa Indonesia), bahasa adalah sistem lambang bunyi yang arbiter, yang dipergunakan oleh sekelompok masyarakat untuk bekerjasama, berinteraksi, dan mengidentifikasikan diri. Dilihat dari pengertian yang ada dalam kamus tersebut, dapat difahami bahwa bahasa juga dapat berfungsi sebagai lambang bunyi sebagai mana not yang ada pada nada, akan tetapi fungsi atau manfaat yang diberikan sangatlah berbeda antara keduanya. Bunyi yang dihasilkan oleh bahasa dipreoritaskan untuk menyampaikan suatu informasi serta lebih menitik beratkan pada kepadatan isinya bukan pada fungsi estetika yang dihasilkannya.

Pengertian Bahasa Menurut Kridalaksana (1983) dan Kentjono (1982), bahasa adalah sistem lambang bunyi yang arbitrer yang digunakan oleh anggota kelompok sosial untuk bekerja sama, berkomunikasi, dan mengidentifikasikan diri. Lain halnya dengan Owen dalam Setiawan (2006:1), yang menjelaskan definisi bahasa yaitu language can be defined as a socially shared combinations of those symbols and rule governed combinations of those symbols (bahasa dapat didefenisikan sebagai kode yang diterima secara sosial atau sistem konvensional untuk menyampaikan konsep melalui kegunaan simbol-simbol yang dikehendaki

\section{DISKUSI}

- Bahasa adalah sistem simbol bunyi yang bermakna dan berartikulasi (dihasilkan oleh alat ucap) yang bersifat arbitrer dan konvensional, yang dipakai sebagai alat berkomunikasi oleh sekelompok manusia untuk melahirkan perasaan dan pikiran. 
- Bangsa Indonesia yang terdiri dari berbagai suku bangsa dan bahasa, memiliki bahasa pemersatu, yaitu bahasa Indonesia.

- Bahasa Indonesia sebagai alat komunikasi berfungsi sebagai alat untuk mengkomunikasikan gagasan, perasaan, dan keinginan kepada orang lain agar dipahami dan direspon.

- Komunikasi bisa berlangsung apabila terdapat unsur atau komponen yang mendukung berlangsungnya proses komunikasi yaitu pihak yang bekomunikasi, informasi atau pesan yang dikomunikasikan, dan alat yang digunakan untuk dikomunikasikan.

- Komunikasi bisa berlangsung dengan baik tergantung media yang digunakan terutama bahasa adalah media yang baik dapat dimengerti dan tidak menyinggung orang lain.

\section{REFERENSI}

[1] A. S. Putra And O. M. Febriani, "Knowledge Management Online Application In Pdam Lampung Province," In Prosiding International Conference On Information Technology And Business (Icitb), 2018, Pp. 181-187.

[2] A. S. Putra, O. M. Febriani, And B. Bachry, "Implementasi Genetic Fuzzy System Untuk Mengidentifikasi Hasil Curian Kendaraan Bermotor Di Polda Lampung," J. Sist. Inf. Dan Manaj. Basis Data, Vol. 1, No. 1, Pp. 21-30, 2018.

[3] O. M. Febriani And A. S. Putra, "Sistem Informasi Monitoring Inventori Barang Pada Balai Riset Standardisasi Industri Bandar Lampung," J. Inform., Vol. 13, No. 1, Pp. 90-98, 2014. [4] Putra, Arie Setya. "2018 Artikel Struktur Data, Audit Dan Jaringan Komputer." (2018).

[5] Putra, A. S. (2018, July 17). Paperplain Fundamental Create Application With Borland Delphi 7.0 University Of Mitra Indonesia. Retrieved From Osf.Io/Pbrn9. 
